\title{
SSinteza
}

Impact of Internet on Business Activities in Serbia and Worldwide

Uticaj Interneta na poslovanje u Srbiji i svetu

DOI: 10.15308/SINTEZA-2014-846-852

\section{SISTEMI PREPORUKE U E-TRGOVINI}

\author{
Aleksandar Simović \\ Visoka škola elektrotehnike i računarstva strukovnih studija Beograd, Srbija
}

\begin{abstract}
:
U radu su opisani sistemi preporuke u elektronskoj trgovini. Prikazana je praktična realizacija sistema za preporučivanje proizvoda u e-trgovini na primeru CMS elektronske prodavnice knjiga Visoke škole elektrotehnike i računarstva strukovnih studija u Beogradu. Predstavljen je sveobuhvatan pregled sistema za preporučivanje proizvoda koji predstavlja važno sredstvo e-trgovine a osnovni cilj je podrška donošenju odluka u procesu kupovine.
\end{abstract}

\section{Key words:}

sistemi preporuke, e-trgovina,, CMS.

\section{UVOD}

Ekspanzivan razvoj informaciono-komunikacione tehnologije i brze novčane transakcije stvaraju utisak da se svet rapidno smanjuje. Roba proizvedena u jednoj zemlji, lako pronalazi kupce u drugoj. Radi se o novom vremenu globalizacije u kojem treba voditi utakmicu sa konkurencijom koja dolazi iz različitih svetskih regiona. U takvoj situaciji neophodno je primenjivati inovacije i rešenja $u$ oblasti elektronskog poslovanja i elektronske trgovine, kako bi efikasnost ekonomske organizacije bila visoka i kako bi kompanija mogla da podnese konkurenciju u novim uslovima [1].

Mnogi od najvećih e-commerce sajtova koriste sisteme za preporučivanje proizvoda da pomognu svojim klijentima da nađu prikladne proizvode za kupovinu. U cilju ostvarivanja osnovne njihove funkcije, sistemi preporuka moraju proceniti i predvideti koji proizvod je za kupca vredan preporučivanja.

\section{INTELIGENTNI AGENTI}

Inteligentni agenti su softverska rešenja dizajnirana da samostalno ili na osnovu zahteva korisnika preduzimaju određene akcije na vebu. Oni imaju mogućnost filtriranja informacija, obrade i povezivanja mnoštva dostupnih podataka. Inteligentnost agenata je u direktnoj vezi sa sledećim osobinama:

- Učenje - sposobnost agenata da tokom svog rada prikupljaju nova znanja.

- Autonomnost - sposobnost agenata da u svom egzistiranju samostalno obavljaju postavljene zadatke.

- Komunikativnost - sposobnost agenata da komuniciraju sa okruženjem.
- Personifikacija - sposobnost agenata da se prilagode korisničkim preferencijama tokom svog rada.

- Poverljivost \& Mobilnost - sposobnost agenata za kretanje kroz različite softverske platforme obezbeđujući poverljivost podataka.

Konceptualno su evoluirali iz objektno-orijentisanog programiranja i razvoja softvera zasnovanog na komponentama (eng. Component-Based). Inteligentni agenti dobijaju zadatke i prioritete od korisnika, traže informacije na veb izvorima, komuniciraju sa drugim agentima, upoređuju informacije o zahtevima i podešavanjima korisnika, vrše izbor informacija, i daju odgovore korisniku. Agenti ne zamenjuju korisnika na vebu, niti obavezno donose odluke, već je u većini slučajeva njihova uloga da prikupe, organizuju i predstave korisniku skup mogućih informacija. Inteligentni agenti koriste: metapodatke za identifikaciju i izdvajanje informacija sa veb izvora; ontologije za pomoć u veb pretragama, za interpretiranje preuzete informacije i za komunikaciju sa drugim agentima; logiku za obradu preuzetih informacija i donošenje zaključaka.

U cilju ostvarivanja osnovne njihove funkcije, inteligentni agenti u sistemima preporuka treba da procene $i$ da predvide koji proizvod je za korisnika vredan preporučivanja. Da bi to mogao da uradi, agent mora biti sposoban da uporedi karakteristike određenih proizvoda i tada da donese odluku koji proizvod će biti preporučen a koji ne. Predikcija jednog jednostavnog, nepersonalizovanog algoritma za preporučivanje koji kupcu daje preporuku samo najpopularnijih i najbolje ocenjenih proizvoda nije racionalan jer su odsutne mnoge, potrebne i preciznije informacije o preferencijama korisnika, ocena drugih korisnika, njihove preporuke proizvoda, kao i informacije o broju korisnika koji su kupili posmatrani proizvod. 


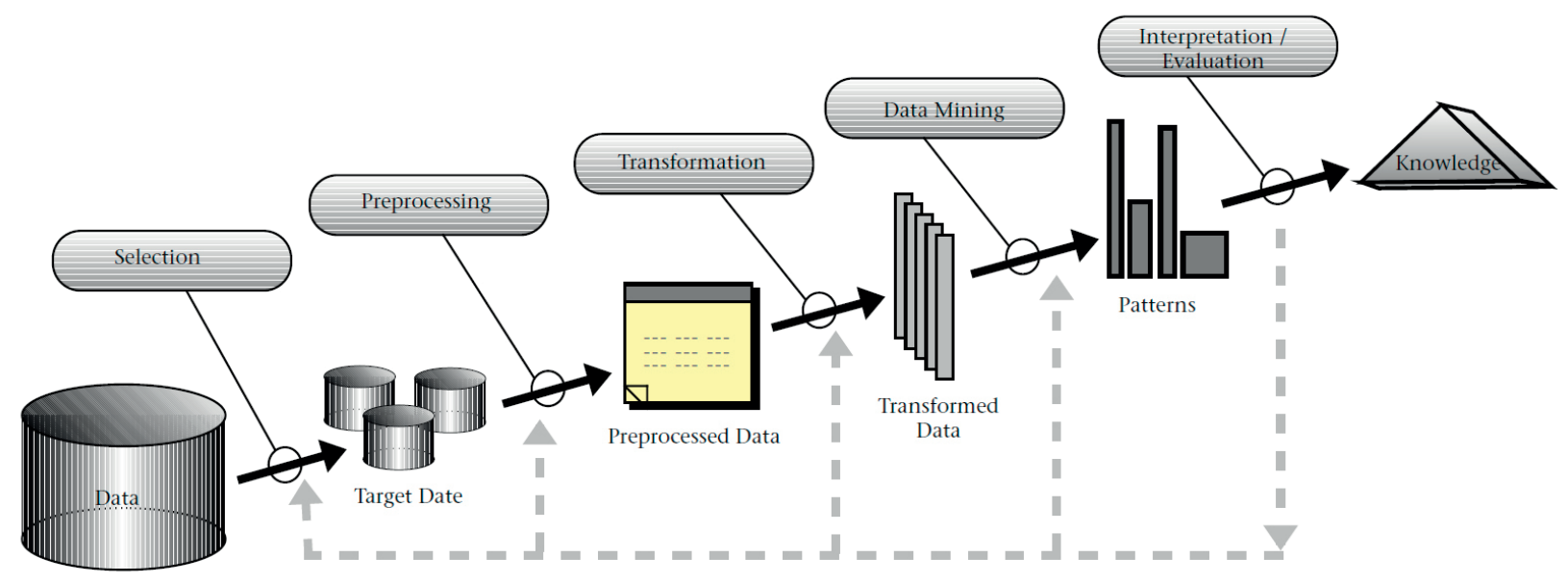

Sl. 1. Faze u procesu otkrivanja znanja (Knowledge-Based Systems) [2]

\section{SISTEMI PREPORUKE U E-TRGOVINI}

Neki sistemi preporuke u e-trgovini su karakteristični po tome što ne procene u potpunosti korisnost određenog proizvoda pre generisanja preporuke, ali ti sistemi mogu da primene metode i tehnike rešavanja problema, učenja i otkrivanja znanja baziranih na iskustvu za hipotezu da je proizvod od koristi za korisnika. To je karakteristično za sisteme zasnovane na znanju (eng. Knowledge-Based Systems) [3], Sl. 1. Ove sisteme za preporučivanje pokreću algoritmi koji koriste razne vrste znanja o korisnicima, njihovim potrebama i preferencijama. Na primer, sistem može pretpostaviti da je funkcija korisnosti iz određene kategorije proizvoda i logički utvrđuje da li je ili ne preporuka koju generiše za kupca korisna. Prema tome, pod pretpostavkom da postoji neko dostupno znanje o korisniku koji traži preporuku; znanja o posmatranom proizvodu; znanje o drugim korisnicima koji su dobili preporuke, sistem uz odgovarajući algoritam koristi za generisanje predviđanja i preporučivanje proizvoda.

Sistemi za preporučivanje proizvoda definišu skup sadržaja koji za posmatranog korisnika mogu biti potencijalno korisni ili se nalaze u području njegovog interesa. U odnosu na način generisanja, sistem korisniku može ponuditi jednu ili više preporuka. Da bi bio u mogućnosti da odredi i generiše što tačniju preporuku i korisnost proizvoda, sistem treba da uvažava više kriterijuma za predstavljanje korisnosti određenog proizvoda baziranih na proširenom skupu podataka o korisniku i proizvodima koji se preporučuju. Obzirom na tehnike i algoritme koji se koriste pri proceni korisnosti proizvoda, osnovni sistemi za preporučivanje se mogu podeliti na [4]:

\section{Sistemi preporuke zasnovan na sadržaju (eng. Content-Based Recommendations)}

Kod sistema za preporuke baziranih na sadržaju, pristup se zasniva na pretpostavci da će korisnost proizvoda biti sličnih karakteristika onima koje je korisnik preferirao u prošlosti. Sistem tako na osnovu prethodno ocenjenih ili odabranih sadržaja nastoji pretpostaviti šta korisnik prefe- rira. Sistem se oslanja na ručna ili automatski generisana pravila koja se koriste kao preporuka proizvoda korisnicima. Mnogi postojeći e-commerce veb sajtovi koji koriste personalizaciju ili preporuku tehnologije, generišu preporuku zasnovano na sadržaju proizvoda. Takvi sistemi omogućavaju administratorima e-prodavnica da odrede pravila, često zasnovana na demografskim ili drugim ličnim karakteristikama korisnika. Pravila se koriste da utiču na sadržaj kojim se služi korisnik čiji profil ispunjava jedan ili više pravila.

Prilikom generisanja preporuka, preferencije korisnika se utvrđuju na bazi karakteristika proizvoda koje je odabrao ili ocenio. Dalje se ti podaci upoređuju sa karakteristikama svih elemenata, i onda se izdvajaju oni proizvodi koji se po karakteristikama u najvećoj meri podudaraju sa preferencijama korisnika. Na taj način se značajno smanjuje broj potencijalnih proizvoda za preporuku određenom korisniku.

Ocena predstavlja meru kojom se iskazuje ili predviđa koliko je za korisnika određeni sadržaj relevantan. Da bi to bilo moguće, svaki se korisnik opisuje modelom - profilom koji može da sadrži osnovne podatke o korisniku, podatke o njegovim ciljevima, preferencijama i sl. Takođe, svaki se proizvod opisuje skupom karakteristika. Prvi korak u procesu generisanja preporuke je izgradnja modela korisnika. Potrebni podaci se pritom prikupljaju od korisnika (npr. putem upitnika) ili se određuju automatski na temelju interakcije korisnika sa sistemom. U sledećoj fazi podaci iz tog modela upoređuju se sa karakteristikama prozvoda i podacima o ostalim korisnicima kako bi se odredile odgovarajuće preporuke.

U odnosu na način prezentacije preporučenih sadržaja, korisniku se može ponuditi jedna ili više preporuka (npr. preporuka poređanih prema visini ocene). Većina postojećih sistema za preporučivanje koristi jedan kriterijum za predstavljanje korisnosti nekog proizvoda za korisnika, dok se u novijim istraživanjima ukazuje na važnost uvažavanja više kriterijuma kako bi se odredile tačnije preporuke. Pritom se preporuka generiše na temelju proširenog skupa podataka o korisniku i proizvodima koji se preporučuju. 
Kod heurističkih tehnika se predviđanje korisnosti određuje pomoću heurističkih formula, baziranih na metodama za pretraživanje informacija (eng. Information Retrieval) [5]. Primeri takvih metoda su kosinusova sličnost, euklidska udaljenost, Pearson-Spearmanova korelacija. Ovde se predviđanje zasniva na modelu sistema baziranih na znanju koristeći mašinsko učenje i statističke modele poput Bayesovih i neuronskih mreža, stabla odlučivanja i algoritama za klasteriranje.

Jedno od ograničenja koja predstavlja problem za ovu tehniku je ograničena mogućnost automatske analize sadržaja. Uspešnost rada sistema za preporučivanje baziranih na sadržaju zavisi od dostupnih podataka kojima se opisuju proizvodi. Iz tog razloga je potrebno omogućiti automatsko opisivanje proizvoda ili njihove karakteristike pridružiti ručno. Automatsko dodeljivanje karakteristika proizvoda je nekad vrlo složeno (npr. kod opisa multimedijskih sadržaja), dok je ručni opis vremenski zahtevan. Ograničenje sistema za preporučivanje baziranih na sadržaju je i Cold-Start problem [6]. Zbog načina rada sistema, potrebno je da korisnik oceni dovoljan broj sadržaja kako bi mu sistem mogao dati odgovarajuće preporuke. Takođe, nedostatak takvih sistema je i što preporučeni sadržaji često nisu raznovrsni. Zbog načina određivanja korisnosti proizvoda, gde se upoređuju karakteristike pojedinog proizvoda sa profilom korisnika, i preporuke samo onih sadržaja za koje je ta vrednost maksimalna ili vrlo visoka, događa se da se korisniku nikada ne preporučuju proizvodi koji se razlikuju po sadržaju od onoga što je korisnik pregledao ranije (eng. Content Overspecialization Problem), već međusobno vrlo slični sadržaji (eng. Non Diversity Problem) [7].

\section{Sistemi kolaborativnog filtriranja (eng. Collaborative Filtering)}

Sistemi za kolaborativno filtriranje nastoje da predvide korisnost pojedinog proizvoda za nekog korisnika na osnovu vrednovanja tog proizvoda od strane ostalih korisnika sistema. Kod sistema za kolaborativno filtriranje, ocene koje su korisnici dodelili proizvodima koriste se kao aproksimativna prezentacija njihovih interesa i potreba. Za razliku od preporuka na osnovu sadržaja, modeli ne sadrže podatke o proizvodima već se ocene dodeljene od strane ciljnog korisnika upoređuju sa ocenama koje su dodelili drugi korisnici sistema pa se određuje njegov najbliži skup proizvoda od interesa. Time je uz model ciljnog korisnika, veoma važna i baza podataka sa modelima ostalih korisnika sistema. Posmatranom korisniku će među proizvodima koje još nije ocenio biti preporučeni oni koje su visoko ocenili njemu slični korisnici. Pristupi kolaborativnom filtriranju se razlikuju upravo po načinu na koji se određuje sličnost između korisnika.

Sistemi za kolaborativno filtriranje klasifikuju se na bazi različitih formulacija u dva osnovna pristupa [8]:

- Kolaborativno filtriranje zasnovano na korisnicima (eng. User-Based).

- Kolaborativno filtriranje zasnovano na proizvodima (eng. Item-Based).
Kod kolaborativnog filtriranja baziranog na korisnicima, vrednovanje proizvoda posmatranog korisnika upoređuje sa vrednovanjem ostalih korisnika kako bi se odredila grupa sličnih korisnika. Preporučuju se proizvodi koje su drugi korisnici ocenili najvišim ocenama. $\mathrm{Na}$ taj način se posmatranom korisniku preporučuju sadržaji koje preferiraju njemu slični korisnici.

Sa druge strane, kod kolaborativnog filtriranja baziranog na proizvodima, za sadržaje koje je posmatrani korisnik pregledao, kupio ili ocenio pronalaze se i preporučuju slični sadržaji. Prilikom određivanja sličnosti među sadržajima upoređuje se vrednovanje posmatranog korisnika $\mathrm{s}$ vrednovanjem ostalih korisnika sistema. Ciljnom korisniku se preporučuju sadržaji koji su ostali korisnici slično vrednovali. U oba navedena slučaja, skup sadržaja za preporuku ograničen je na one proizvode koje su ocenili ostali korisnici. Sistemi za kolaborativno filtriranje rešavaju neke probleme navedene kod sistema za preporučivanje zasnovane na sadržaju. Preporuke su nezavisne u odnosu na sadržaj, jer se prilikom generisanja preporuka koriste ocene ostalih korisnika, a ne karakteristike sadržaja koji se preporučuju. Uz to, takav način rada omogućava da se korisniku preporuče proizvodi koji se sadržajno razlikuju od onoga što je korisnik pregledao ranije.

Međutim, sistemi za preporučivanje kod kojih se implementiraju samo tehnike kolaborativnog filtriranja takođe imaju određene nedostatke. Jedan od njih je problem malog broja ocena (eng. Sparse Rating Problem) koji je naročito prisutan kod sistema s velikim brojem proizvoda koje je moguće preporučiti. Kako uspešnost tehnika kolaborativnog filtriranja zavisi od upoređivanja proizvoda koji su vrednovani od strane korisnika, problem se javlja kada je dostupan mali broj ocena. Proizvodi koji su vrednovani od strane malog broja korisnika gotovo nikada neće biti preporučeni, nezavisno od visine ocena. Takođe, ako se skup sadržaja nekog proizvoda često menja, ranije dodeljene ocene neće koristiti novim korisnicima jer ti proizvodi neće biti obuhvaćeni algoritmom za generisanje preporuka.

I kod kolaborativnog filtriranja se javlja Cold-Start problem za nove korisnike. Ukoliko na početku rada sa sistemom nema ocenjenih sadržaja od strane korisnika, nije moguće generisati odgovarajuće preporuke koristeći kolaborativno filtriranje. Isti se problem javlja i u slučaju novog sadržaja u sistemu. Sve dok novi sadržaj ne oceni dovoljan broj korisnika, sistem ga neće preporučivati. Taj je problem posebno izražen kod sistema gde postoji stalan unos novih sadržaja. Kako se kod kolaborativnog filtriranja znanje sistema o proizvodima zasniva na tome što korisnici preferiraju, preporuke zavise u potpunosti od toga koje sadržaje korisnici ocenjuju. Korisnici čija se interesovanja razlikuju u odnosu na ostale učesnike i za koje je teško naći slične korisnike ne mogu od sistema za preporuke koji se zasniva na kolaborativnom filtriranju baziranom na korisnicima očekivati dobre rezultate. Naime, kolaborativno filtriranje se pokazalo uspešno za one korisnike koji se mogu svrstati u grupu najbližih resursa (klastere), dok za korisnike za koje to nije moguće, nije moguće ni ponuditi odgovarajuće preporuke. Uz navedeno, treba spomenuti i problem raznovrsnosti sadržaja 
(eng. Non Diversity Problem). Kako se kod kolaborativnog filtriranja znanje sistema o resursima zasniva na tome što korisnici preferiraju, preporuke zavise u potpunosti od toga koje sadržaje korisnici ocenjuju, što rezultira preporučivanjem samo najpopularnijih sadržaja.

Sistemi za kolaborativno filtriranje se često prilikom generisanja preporuka oslanjaju isključivo na vrednovanje resursa od strane korisnika. Ne uzimaju u obzir dodatne informacije zavisne od konteksta koje kod nekih primena ne treba zanemariti, jer korisnost nekog proizvoda može da se razlikuje zavisno od okolnosti u kojima će biti korišćen.

\section{Hibridni sistemi preporuke (Hybrid Recommender Systems)}

Mešoviti ili hibridni sistemi za preporučivanje kombinuju generisanje preporuka zasnovanih na sadržaju i kolaborativnom filtriranju i nastoje prevladati ograničenja pojedinih pristupa uzimajući u obzir karakteristike sadržaja i vrednovanje sadržaja od strane korisnika. Pristupi implementaciji se mogu klasifikovati zavisno od načina kombinovanja različitih tehnika za generisanje preporuka. Neke od mogućnosti su da se na osnovu određenog kriterijuma vrši izmena korišćenih tehnika u nekoliko faza, da se primenom jedne tehnike dobija model koji služi kao ulaz za sledeću tehniku ili da se zajedno prezentuju preporuke dobijene na osnovu različitih tehnika [9].

Iako se mešovitim pristupima pokušavaju otkloniti nedostaci sistema za generisanje preporuka zasnovanih na sadržaju i korišćenjem kolaborativnog filtriranja, kod postojećih sistema za preporuke se mogu identifikovati i neki opšti nedostaci.

\section{REALIZACIJA INTELIGENTNOG AGENTA}

Za realizaciju inteligentnog agenta za preporučivanje proizvoda korišćen je Open Source CM sistem za upravljanje sadržajem elektronskih prodavnica - osCommerce.

Elektronska prodavnica korišćenjem Open Source softvera je jednostavan način realizacije e-trgovine. CM Open Source sistemi za upravljanje sadržajem podržani su zajednicom dizajnera i programera koji redovno rade na njihovom usavršavanju. Sva rešenja imaju online podršku u vidu dodatnih modula i komponenti, kao i foruma za komunikaciju sa korisnicima. Open Source softver je softver koji je besplatan za preuzimanje, instalaciju, nadogradnju i korišćenje čiji je izvorni kôd dostupan unutar Open Source licence svim korisnicima. Može se menjati, prepravljati i poboljšavati njegov sadržaj. To znači da uz Open Source softver dolazi i čitav izvorni kôd u njegovom programskom jeziku, što nije slučaj sa plaćenim softverom. Naravno, održavanje i rad elektronske prodavnice zahteva i angažovanje stručnjaka, školovanih za tu vrstu posla ili obukom zaposlenih čija uloga se sada značajno menja u poslovnom sistemu [10].

E-prodavnica koristi inteligentnog agenta za preporučivanje proizvoda na principu kolaborativnog filtriranja (eng. Collaborative Filtering) zasnovanom na filtriranju po proizvodima (eng. Item-Based).
Način na koji inteligentni agent za preporučivanje proizvoda rešava problem generisanja preporuka, može se formalno zapisati na sledeći način [11]: neka je $U=(u$, $\left.u_{2}, \ldots, u_{m}\right)$ skup korisnika sistema, $I=\left(i_{1}, i_{2}, \ldots, i_{n}\right)$ skup svih proizvoda (items) koji se mogu preporuciiti, a $R$ potpuno uređeni skup. Neka je $g: U X I \rightarrow R$ funkcija korisnosti (Utility function). Vrednost funkcije $g\left(u_{j}, i_{k}\right)$ predstavlja korisnost proizvoda $i_{k}$ za korisnika $u_{j}$.

Cilj sistema je: za svakog korisnika $u_{j} \in U$ odrediti proizvod $i^{\max , u_{j}} \in I$ za koji je vrednost funkcije $g$ maksimalna:

$$
\forall u_{j} \in U, i^{\max , u_{j}}=\underset{i_{k} \in I}{\arg \max } g\left(u_{j}, i_{k}\right)
$$

Uobičajeno je korisnost nekog proizvoda vrednovati brojčanom ocenom koju će odrediti sam korisnik ili će se ona izračunati. Ocena pritom ne mora biti vrednost koju je određeni korisnik dodelio proizvodu, već se može izraziti i brojem pregleda proizvoda, brojem kupljenih primeraka i sl.

Ocena predstavlja meru kojom se iskazuje (ili predviđa) koliko je za korisnika određeni sadržaj relevantan. Da bi to bilo moguće, svaki se korisnik $u_{j} \in U$ opisuje modelom, profilom koji može uključivati osnovne podatke o korisniku, podatke o njegovim ciljevima, preferencama i sl. Takođe, svaki se proizvod $i_{k} \in I$ opisuje skupom karakteristika. Centralni problem sistema za preporuke je što u većini slučajeva funkcija $g$ nije definisana na celom skupu UXI, već samo na njegovom podskupu. Inicijalno je ocena poznata samo za one proizvode koje su korisnici prethodno ocenili, dok se za nepoznate vrednosti ona zasniva na predviđanju. Prema tome, jedan od ciljeva sistema za preporuke je i što tačnije predvideti ocene za neocenjene proizvode zasnovane na poznatim ocenama. Nakon predviđanja vrednosti za sve uređene parove skupa UXI, preporuka za određenog korisnika se određuje prema jednačini (1). U zavisnosti od načina prezentacije preporučenih sadržaja, korisniku se može ponuditi jedna ili više preporuka (npr. lista od $n$ preporuka poređanih prema visini ocene).

Većina postojećih sistema za preporuke koristi jedan kriterijum za predstavljanje korisnosti nekog proizvoda za korisnika u skupu UXI, dok se u novijim istraživanjima [12] ukazuje na važnost uvažavanja više kriterijuma kako bi se odredile tačnije preporuke. Pritom se preporuka generiše na zasnivanju proširenog skupa podataka o korisniku i proizvodima koji se preporučuju. Funkcija $g$ se tada može definisati na sledeći način: $g: U \mathrm{XI} \rightarrow R_{0} \mathrm{X} R_{1} \mathrm{X}$ $\ldots \mathrm{X} R_{l}$ gde je $R_{0}$ skup mogućih ukupnih ocena i korisnosti određenog proizvoda, a skupovi $R_{c} c=1, \ldots, l$ skupovi mogućih ocena prema kriterijumima $c, c=1, \ldots, l$.

Za razliku od ukupne ocene iz skupa $R_{0}$, ocene po kriterijumima omogućavaju podatak o tome zašto posmatrani proizvod korisnik preferira, a ne samo koliko ga preferira. Takođe, zasnivanje ocena po kriterijumima moguće je preciznije odrediti sličnosti među korisnicima sistema.

Način na koji sistem za preporučivanje proizvoda, metodom kolaborativnog filtriranja nastoji predvideti korisnost pojedinog proizvoda za nekog korisnika bazira se na osnovu vrednovanja proizvoda od strane ostalih korisnika sistema na sledeći način: 
Vrednost funkcije $g\left(u, i_{k}\right)$ kojom se predstavlja korisnost proizvoda $i_{k} \in I$ za korisnika $u_{j} \in U$ se u tom slučaju procenjuje i zasniva na poznatim vrednostima $g\left(u_{s} i_{k}\right)$ za proizvod $i_{k}$ pri čemu je korisnik $u_{s} \in U$ sličan korisniku $u_{k}$ $\in U$.

Definiše se model, profil korisnika, u oznaci CollaborativeUserProfile (u ), kao vektor čije su komponente ocene koje je korisnik dodelio proizvodima dostupnim u sistemu:

CollaborativeUserProfile $\left(u_{m}\right)=\mathrm{r}_{m}=\left(r_{m, 1}, r_{m, 2}, \ldots, r_{m, n}\right) \in R^{N}$

Ocene koje su određenom proizvodu dodelili ostali korisnici predstavljaju se vektorom $\operatorname{Ratings}\left(i_{n}\right)$ :

$\operatorname{Ratings}\left(i_{n}\right)=r_{n}=\left(r_{1, n} r_{2, n}, \ldots, r_{M, n}\right) \in R^{M}$

U slučaju da korisnik $u_{i}$ nije ocenio sadržaj $i_{j}$ za komponentu $r_{i, j}$ u oba gore navedena vektora vredi $r_{i, j}=\emptyset$. Vrednost korisnosti proizvoda $i_{n} \in I$ za korisnika $u_{m} \in U$ određuje se funkcijom score koja pri izračunavanju kombinuje komponente profila korisnika $u_{m}$ i ocene za $i_{n}$ :

$$
g\left(u_{m}, i_{n}\right)=\operatorname{score}\left(\text { CollaborativeUserProfile }\left(u_{m}\right) \text {,Ratings }(\right.
$$
$\left.\left.i_{n}\right)\right) \in R$

Način rada inteligentnog agenta u sistemu preporuke

Umesto da upoređuje korisnike sa kupcima sličnih preferencija, kolaborativno filtriranje bazirano na filtriranju po proizvodima upoređuje izvršenu svaku kupovinu ostvarenog kupca, rangira proizvode po sličnosti, i kombinacijom sličnih proizvoda generiše preporuku.

Algoritam generiše tabelu sličnosti da bi utvrdio proizvod koji je najprikladniji korisniku na njegov zadati upit. Način na koji algoritam izračunava sličnosti između posmatranog proizvoda sa svim drugim proizvodima elektronskog kataloga je iskazan u sledećem pseudo kôdu [13]

For each item in product catalog. $I_{1}$

For each customer $C$ who purchased $I_{1}$

For each item $I_{2}$ purchased by

customer $C$

Record that a customer purchased $I_{1}$

and $I_{2}$

For each item $I_{2}$

Compute the similarity between $I_{1}$ and $I_{2}$

Moguće je izračunavanje sličnosti između dva proizvoda na različite načine, ali je uobičajen metod kosinus (cosine) izračunavanja gde svaki vektor korespondira sa proizvodom a ne sa kupcem, dok vektor $M$-dimenzije korespondira sa kupcem koji je obavio kupovinu tog proizvoda.

Kada je reč o e-prodavnicama velikih skladišta podataka, ovakav način izračunavanja za generisanje tabele sličnih proizvoda zahteva vreme sa slučajem $O(N 2 M)$. Međutim, u praksi je bliže slučaju $O(N M)$ jer mnogi kupci imaju manji broj ostvarenih kupovina.

Algoritam za kolaborativno filtriranje prezentuje npr. kupca sa $\mathrm{N}$-dimenzionalnim vektorom proizvoda, gde je $N$ broj proizvoda elektronskog kataloga. Komponente vektora su pozitivne za obavljanje kupovine ili pozitivno ocenjene dok su negativne komponente vektora negativno rangirane. Kompenzacijom, radi najbolje prodaje proizvoda elektronskog kataloga, algoritam multiplicira komponente vektora invertujući frekvenciju (invertuje broj kupaca koji su kupili ili ocenili proizvod) stvarajući manje poznate proizvode više relevantne.

Skoro za sve kupce, prilikom odabira proizvoda za kupovinu, prikaz preporuka korišćenjem ovog vektora je redak. Algoritam generiše preporuke bazirane na samo nekoliko kupaca sličnih preferencija u odnosu na posmatranog korisnika.

Preferencije i sličnosti dva kupca, $A$ i $B$, agent može meriti na različite načine. Često primenjivan metod je izračunavanje kosinusa ugla između dva vektora, prikazan u jednačini (2).

$$
\operatorname{similarity}(\vec{A}, \vec{B})=\cos (\vec{A}, \vec{B})=\frac{\vec{A} \bullet \vec{B}}{\|\vec{A}\| *\|\vec{B}\|}
$$

Inteligentni agent preporučuje proizvode na osnovu sličnosti proizvoda korišćenjem različitih metoda. Uobičajena tehnika generisanja preporuke je rangiranje svakog proizvoda elektronskog kataloga je na osnovu toga koliko je kupaca kupilo isti proizvod.

Ako je $O(M N)$, gde je $M$ broj ostvarenih kupaca i $N$ broj proizvoda u elektronskom katalogu, sistem istražuje $M$ kupaca do $N$ proizvoda za svakog kupca. Međutim, iz razloga što je prosečan vektor kupca izuzetno redak, performansa algoritma agenta teži blizini $O(M+N)$.

Skeniranje svakog ostvarenog kupca je približno $O(M)$, a ne $O(M N)$. Razlog tome je što vektor skoro svakog kupca sadrži mali broj proizvoda, bez obzira na veličinu podataka u katalogu. Međutim postoji mali broj kupaca koji su obavili kupovinu ili ocenili mali broj proizvoda iz elektronskog kataloga, zahtevajući $O(N)$ vreme izvršavanja. Tako je finalna performansa algoritma približna $O(M+N)$.

Kod e-prodavnica koje skladište velike količine podataka, npr. milion i više kupaca $\mathrm{i}$ isto toliko proizvoda $\mathrm{u}$ katalogu, pomenuti način preporučivanja ne bi bio elegantno rešenje jer bi se algoritam susreo sa poteškoćama davanja očekivanih kalkulacija, performansi i skaliranja podataka.

Moguće je delimično rešenje problema skaliranja, smanjivanjem količine skladištenih podataka ukoliko je baza preopterećena, što važi za velike e-prodavnice sa milionskim skladištem proizvoda. $M$ se može smanjiti slučajnim uzorkom kupaca iz baze, odbacivanjem kupaca koji su izvršili manji broj kupovina; dok se $N$ može smanjiti odbacivanjem ili veoma popularnih ili nepopularnih proizvoda. Korišćenje tehnika za smanjivanje kao što je clustering i detaljnom Međutim, ponuđeno rešenje problema i pomenute tehnike za smanjivanje baze utiču na kvalitet inteligentnog agenta za preporučivanje na mnogo načina. Algoritam istražuje samo mali uzorak kupaca, tako da posmatranom korisniku, agent neće davati ispravne preporuke; ako algoritam odbaci ili najpopularnije ili najnepopularnije proizvode, oni se više neće pojavljivati kao preporuke i kupci koji su obavili kupovine tih proizvoda, neće dobiti preporuke.

Praktičan primer implementiranog, funkcionalnog inteligentnog agenta za preporučivanje proizvoda u elektronskoj trgovini na primeru e-prodavnice knjiga VISER koja se može naći na veb lokaciji: www.prodavnicaknjiga.rs [14] i prikaz generisane preporuke prilikom izbora odabranog proizvoda za kupovinu, prikazan je na slici 2. 


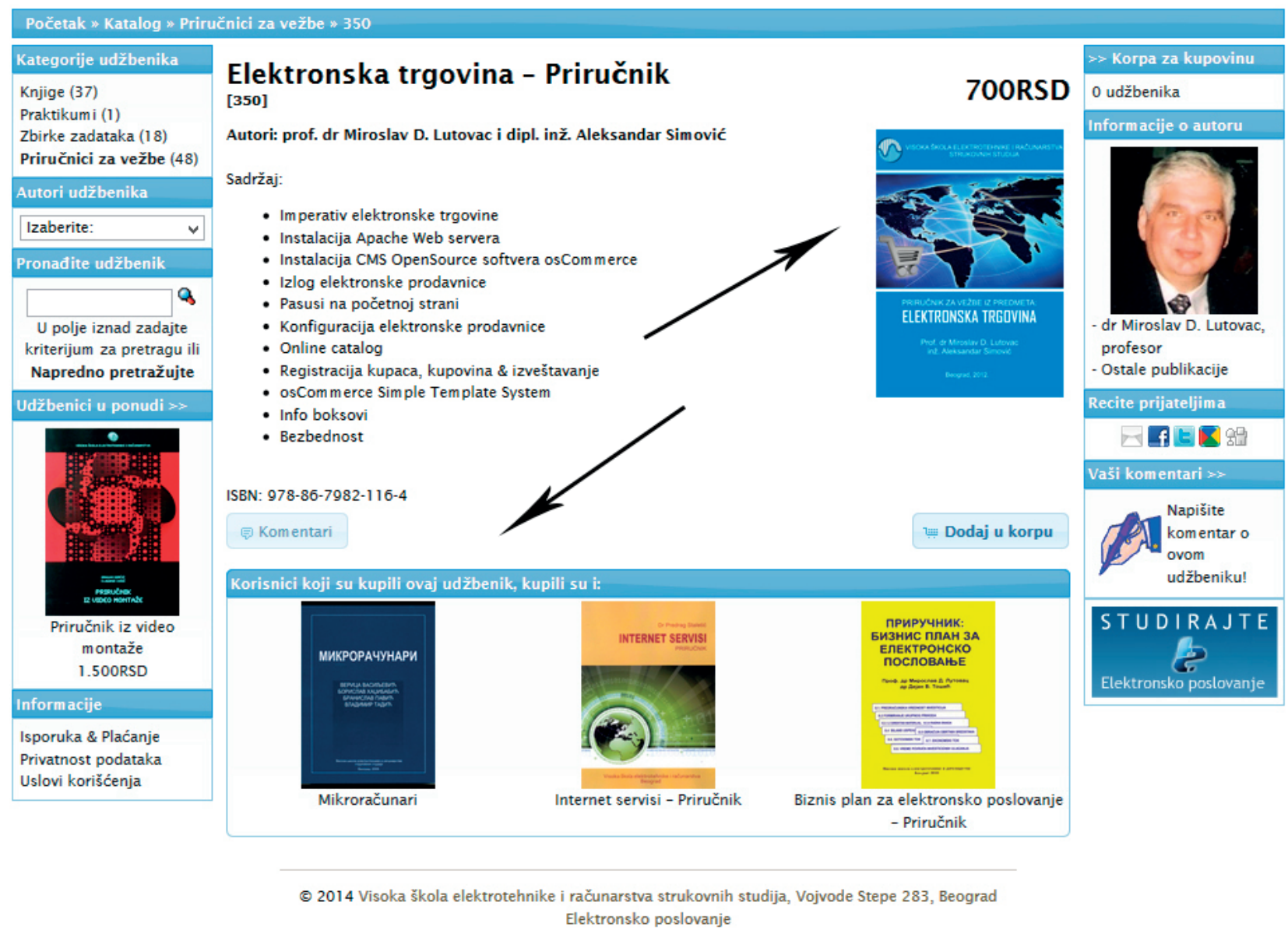

Sl. 2. Inteligentni agent za preporučivanje proizvoda ( $w w w$.prodavnicaknjiga.rs) analizom komponenata rezultuje umanjivanjem elemenata $M$ i $N$ velikim faktorom.

\section{ZAKLJUČAK}

Menjaju se navike i potrebe potrošača, brišu se granice između tržišta, kao i finansijski uslovi. Takođe se menja i isplativost koju postiže proizvod na nekom tržištu. Kontinuirano se traže nova tržišta ili novi proizvodi što stvara stalnu potrebu za novim ljudima čiji je stručni profil takođe podvrgnut stalnim promenama. Shodno tome, kompanije moraju da automatizuju svoje poslovanje i povećaju tržišni odziv, a jedan od instrumenata za efikasno držanje koraka sa vremenom je implementacija sistema preporuka $\mathrm{i}$ inteligentnih agenata u e-trgovini.

\section{LITERATURA}

[1] M. Lutovac i A. Simović, "Priručnik za vežbe iz predmeta Elektronska trgovina,” VISER, Beograd, 2012.

[2] J. Srivastava, R. Cooley, M. Deshpande and PN. Tan, "Web usage mining: Discovery and applications of usage patterns from web data,” ACM SIGKDD Explorations, 2000.

[3] U. Fayyad, G. Piatetsky-Shapiro and P. Smyth, "From Data Mining to Knowledge Discovery in Databases, " AI Magazine, 1996.
[4] M. Wooldridge and N. R. Jennings, "Intelligent agents: theory and practice," The Knowledge Engineering Review, vol. 10, Cambridge University Press, 1995.

[5] M. W. Berry, S. T. Dumais and G. W. O’Brien, "Using linear algebra for intelligent information retrieval," SIAM Review, vol. 37, 1995.

[6] A. I. Schein, A. Popescul and L. H. Ungar, "Methods and metrics for cold-start recommendations," Proceedings of the 25th annual international ACM SIGIR conference on Research and development in information retrieval, ACM New York, 2002.

[7] T. Zhou, Z. Kuscsik, J. G. Liu, M. Medo, J. R. Wakeling and Y. C. Zhang, "Solving the apparent diversity-accuracy dilemma of recommender systems," Proceedings of the National Academy of Sciences of the United States of America, 2010.

[8] J. L. Herlocker, J. A. Konstan, L. G. Terveen and J. T. Riedl, "Evaluating collaborative filtering recommender systems," ACM Transactions on Information Systems, vol. 22, ACM New York, 2004.

[9] R. Burke, "Hybrid recommender systems: Survey and experiments," User Modeling and User-Adapted Interaction, vol. 12, Springer, 2002. 
[10] P. Staletić, A. Simović i M. Lutovac, "Elektronska prodavnica korišćenjem open-source softvera," TELFOR, Beograd, 2010.

[11] I. Cantador, A. Bellogín and P. Castells, "A Multilayer Ontology-based Hybrid Recommendation Model," AI Communication 21, IOS Press, 2008.

[12] F. Ricci, L. Rokach, B. Shapira and P. B. Kantor, "Recommender Systems Handbook,” Springer, New York, 2011.
[13] G. Linden, B. Smith and J. York, “Amazon.com recommendations: item-to-item collaborative filtering," Internet Computing, IEEE, vol. 7, 2003.

[14] www.prodavnicaknjiga.rs, datum pristupa: 1. mart 2014.

\section{RECOMMENDER SYSTEMS IN E-COMMERCE}

\section{Abstract:}

The paper describes the system recommendations in electronic commerce. It shows the practical implementation of an e-commerce recommending system on the example CMS electronic book stores of the College of Electrical Engineering and Computer Science Applied Studies in Belgrade. Comprehensive overview of the system for recommending products is presented witch is an important mean of e-commerce and the main goal is to support decision making in the buying process.

Key words:

Recommender Systems, e-commerce, CMS. 